\title{
Aplikasi Ekstrak Kulit Buah Naga Merah (Hylocereus polyrhizus) Pada Pembuatan Susu Kedelai (Hylocereus polyrhizus)
}

\author{
Application Of The Rind Extract Of Hylocereus polyrhizus On Making Soybean Milk
}

\author{
Masyhura MD*, Mhd. Iqbal Nusa, Dicky Prasetya \\ Program Studi Teknologi Hasil Pertanian Fakultas Pertanian \\ Universitas Muhammadiyah Sumatera Utara \\ Jln. Kapt. Mukhtar Basri, No. 3 Medan, Indonesia \\ *Email: masyhura@umsu.ac.id
}

\begin{abstract}
ABSTRAK
Penelitian ini bertujuan untuk mengetahui mengetahui pengaruh penambahan ekstrak kulit buah naga dan gum arab terhadap mutu susu kedelai. Penelitian ini menggunakan Rancangan Acak Lengkap (RAL) faktorial dengan (2) dua ulangan.Faktor I adalah penambahan ekstrak kulit buah naga denngan sandi (D) yang terdiri atas 4 taraf yaitu: $\mathrm{D}_{1}=20 \%, \mathrm{D}_{2}=40 \%, \mathrm{D}_{3}=60 \%, \mathrm{D}_{4}=80 \%$. Faktor II adalah penambahan konsentrasi gum arab dengan sandi $(G)$ yang terdiri atas 4 taraf yaitu: $G_{1}=0,1 \%, G_{2}=$ $0,2 \%, \mathrm{G}_{3}=0,3 \%, \mathrm{G}_{4}=0,4 \%$. Parameter yang diamati meliputi kadar protein Antioksidan, $\mathrm{pH}$, organoleptik rasa dan warna. Hasil analisis secara statistik pada masing-masing parameter memberikan kesimpulan sebagai berikut: penambahan ekstrak kulit buah naga memberi pengaruh berbeda sangat nyata $(\mathrm{P}<0,01)$ terhadap kadar protein, antioksidan, $\mathrm{Ph}$,organoleptik rasa dan warna. Penambahan gum arab memberi pengaruh yang berbeda sangat nyata $(\mathrm{P}<0,01)$ terhadap kadar protein, antioksidan, $\mathrm{Ph}$, organoleptik rasa dan warna.
\end{abstract}

Kata Kunci: Buah Naga, Gum Arab, Susu Kedelai

\begin{abstract}
This study aims to determine the effect of adding extracts of dragon fruit and gum arab fruit to soy milk quality. This research used Factorial Random Design (RAL) with (2) two replications. Factor I is the addition of dragon fruit skin extract password (D) which consists of 4 levels, namely: $D_{1}=20 \%, D_{2}$ $=40 \%, \mathrm{D}_{3}=60 \%, \mathrm{D}_{4}=80 \%$. Factor II is the addition of gum arabic concentration with a password $(\mathrm{G})$ consisting of 4 levels, namely: $\mathrm{G}_{1}=0.1 \%, \mathrm{G}_{2}=0.2 \%, \mathrm{G}_{3}=0.3 \%, \mathrm{G}_{4}=0.4 \%$.Parameters observed included protein levels Antioxidants, $\mathrm{Ph}$, organoleptic taste and colors. The result of statistical analysis on each parameter gives the following conclusion: the addition of dragon fruit skin extract gives very significant different effect $(\mathrm{P}<0,01)$ to the protein levels antioxidant, $\mathrm{Ph}$, organoleptic taste and color. The addition gum arab gives very significat different effect $(\mathrm{P}<0,01)$ to the protein levels, antioxidant, $\mathrm{Ph}$, organoleptic taste and color.
\end{abstract}

Keywords: Dragon Fruit, Gum Arab, Soyben Milk

\section{A. PENDAHULUAN}

Susu kedelai dapat menjadi alternatif pengganti susu sapi bagi orang yang alergi dan tidak menyukai susu sapi atau bagi mereka yang tidak dapat menjangkau harga susu sapi yang mahal karena susu kedelai harganya lebih murah jika dibandingkan dengan susu hewani, serta susu kedelai memiliki nilai gizi yang baik dan cocok untuk dikonsumsi untuk semua golongan usia. 
Buah naga termasuk dalam buah yang eksotik karena penampilannya yang menarik, rasanya asam manis menyegarkan dan memiliki beragam manfaat untuk kesehatan. Manfaat buah naga menurut Marhazlina (2008). Dalam penelitiannya adalah sebagai anti hiperkolesterolemik, Konsumsi buah naga merah hanya memanfaatkan buahnya saja,sedangkan limbah kulitnya yang berjumlah $30-35 \%$ berat buah kurang termanfaatkan, padahal menurut Hidayah (2013) terdapat kandungan betasianin sebesar 186,90mg/100g berat kering dan aktivitas antioksidan sebesar $53,71 \%$.

Keunggulan kulit buah naga merah menurut penelitian yang dilakukan oleh Li Chen Wu et al (2005), adalah kaya polyphenol dan sumber antioksidan yang baik. Bahkan menurut studi yang dilakukannya terhadap total phenolic conten, aktivitas antioksidan dan kegiatan antiproliferative, kulit buah naga merah adalah lebih kuat inhibitor pertumbuhan sel-sel kanker dari pada dagingnya dan tidak mengandung toksik. Oleh karena itu kulit buah naga merah sangat layak untuk dijadikan bahan baku produk olahan, salah satunya adalah dijadikan bahan tambahan pewarna alami untuk membuat susu kedelai.

Susu kedelai dan santan merupakan produk nabati berbentuk cair dan berwarna putih, sehingga penambahan pewarna alami dari ekstrak kulit buah naga akan menyebabkan produk memiliki warna yang lebih menarik bagi konsumen untuk mengkonsumsi susu kedelai yang juga mengandung senyawa bioaktif yang sangat baik untuk kesehatan. Mitasari (2012) menyatakan bahwa ekstrak kloroform kulit buah naga merah memiliki aktivitas antioksidan dengan nilai Inhibitor Concentration (IC50) sebesar 43,836 $\mu \mathrm{g} / \mathrm{mL}$. Antioksidan merupakan senyawa yang dapat menghambat reaksi oksidasi dengan mengikat radikal bebas dan molekul yang sangat reaktif sehingga kerusakan sel dapat dihambat (Winarsi, 2007).

Penggunaan gum arab diharapkan dapat digunakan sebagai stabilizier pada pembuatan minuman madu sari buah jambu merah. Gum arab digunakan untuk mendorong pembentukan emulsi yang mantap dan mencegah kristalisasi gula. Gum arab stabil dalam larutan asam dan dapat meningkatkan stabilitas dengan peningkatan viskositas dan mencegah terjadinya pengendapan. Jenis pengental ini juga tahan panas pada proses yang menggunakan panas namun akan lebih baik jika panasnya dikontrol untuk mempersingkat waktu pemanasan karena gum arab dapat terdegradasi secara perlahan lahan dan mengurangi emulsifikasi dan viskositas (Febryanto, 2008).

\section{B. METODOLOGI Bahan dan Alat}

Bahan baku yang digunakan pada penelitian ini adalah kulit buah naga, kacang kedelai dan gum arab. Bahan kimia yang digunakan adalah $\mathrm{K}_{2} \mathrm{SO}_{4}, \mathrm{CuSO}_{4}, \mathrm{NaOH}, \mathrm{H}_{2} \mathrm{SO}_{4}, \mathrm{NaOH}, \mathrm{DPPH}$.

Alat yang digunakan adalah kompor gas, blender, kain saring, ayakan 80 mesh, baskom, pisau, telenan, beker glass, hot plate, magnetic stirer, oven, desikator, plat kaca, soxhlet.

\section{Rancangan Penelitian}

Penelitian ini menggunakan Rancangan Acak Lengkap (RAL) faktorial yang terdiri dari dua faktor yaitu,

Faktor I : Penambahan Ekstrak Kulit Buah Naga Merah dan Faktor II : Konsetrasi Gum Arab

\section{Pelaksanaan Penelitian \\ Pembuatan Ekstraksi Kulit Buah Naga Merah}

1. Ditimbang kulit buah naga

2. Kemudian dibersihkan kulit buah naga dengan air mengalir

3. Kulit buah naga lalu dipotong kecil-kecil.

4. Dimasukkan kedalam blender dengan perbandingan air dan kulit buah naga 1:1

5. Kemudian disaring kulit buah naga

6. Di peroleh ekstrak kulit buah naga

\section{Pembuatan Susu Kedelai}

1. Dibersihkan kedelai dari kotoran yang melekat pada kacang kedelai

2. Direndam kedelai selama 6-8 jam, kemudian tiriskan

3. Kemudian dikupas kulit ari kedelai

4. Dilakukan penggiling menggunakan blender dengan perbandingan air $1: 2$

5. Dilakukan perebusan hingga mendidih, kemudian pisahkan ampas kedelai dengan air rebusan

6. Dinginkan hingga suhu $\pm 50^{\circ} \mathrm{C}$. 
7. Tambahkan ekstrak kulit buah naga sesuai perlakuan faktor 1

8. Tambahkan gum arab sesuai perlakuan faktor 2

9. Dilakukan analisa yang meliputi kadar protein, antioksida, $\mathrm{pH}$, organoleptik rasa dan warna.

\section{HASIL DAN PEMBAHASAN}

\section{Kadar Protein \\ Pengaruh Penambahan Ekstrak Kulit Buah Naga}

Penambahan ekstrak kulit buah naga memberikan pengaruh yang berbeda sangat nyata $(\mathrm{p}<0,01)$ terhadap kadar protein. Tingkat perbedaan tersebut telah di uji dengan uji beda rata-rata dan dapat dilihat pada Tabel 1.

Tabel 1 Hasil Uji Beda Rata-Rata Penambahan Ekstrak Kulit Buah Naga Terhadap Kadar Protein

\begin{tabular}{|c|c|c|c|c|c|c|}
\hline Penambahan & & \multicolumn{2}{|c|}{ LSR } & & \multicolumn{2}{|c|}{ Notasi } \\
\hline $\begin{array}{l}\text { Ekstrak Kulit } \\
\text { Buah Naga (\%) }\end{array}$ & Jarak & 0,05 & 0,01 & Rataan & $\overline{0,05}$ & $\overline{0,01}$ \\
\hline $\mathrm{D}_{1}=20 \%$ & - & - & - & 5.966 & a & A \\
\hline $\mathrm{D}_{2}=40 \%$ & 2 & 0.290 & 0.399 & 5.602 & $\mathrm{~b}$ & A \\
\hline $\mathrm{D}_{3}=60 \%$ & 3 & 0.305 & 0.420 & 5.244 & c & B \\
\hline $\mathrm{D}_{4}=80 \%$ & 4 & 0.312 & 0.430 & 4.154 & $\mathrm{~d}$ & $\mathrm{C}$ \\
\hline
\end{tabular}

Keterangan: Huruf yang berbeda pada kolom notasi menunjukkan pengaruh yang berbeda nyata pada taraf $p<0,05$ dan berbeda sangat nyata pada taraf $p<0,01$

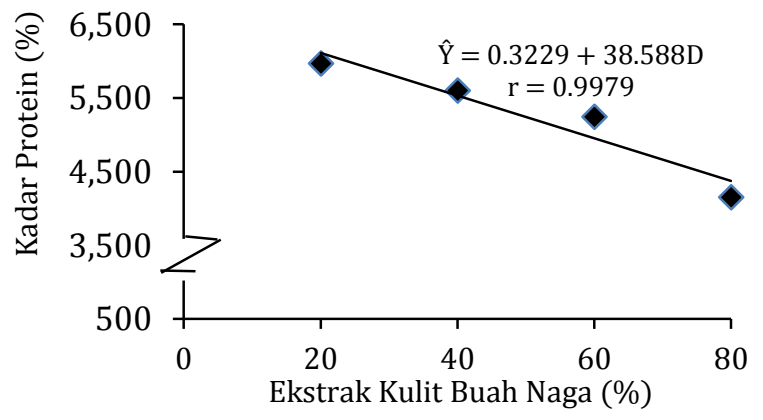

Gambar 1 Pengaruh Penambahan Ekstrak Kulit Buah Naga terhadap Kadar Protein

Pada Gambar 1 dapat dilihat bahwa semakin tinggi penambahan ekstrak kulit buah naga maka kadar protein akan semakin akan menurun. Menurut Wahyuni dan Nugroho (2014), menyatakan karena di dalam ekstrak kulit buah naga merah mengandung protein dalam jumlah yang sedikit. Terjadinya penurunan dalam kadar protein dapat juga disebabkan karena proses pemanasan saat melakukan penelitian. Menurut Sulistyowati (2014), menyatakan adapun pengaruh lain yang dapat mempengaruhi tinggi rendahnya kadar protein pada susu kedelai yang dibuat dikarenakan oleh proses pemanasan yang terlalu lama dapat mengakibatkan denaturasi protein yang terkandung didalam susu kedelai.

\section{Pengaruh Gum Arab}

Dari daftar sidik ragam dapat dilihat bahwa gum arab memberikan pengaruh yang berbeda sangat nyata $(\mathrm{p}<0,01)$ terhadap kadar protein. Tingkat perbedaan tersebut telah di uji dengan uji beda rata-rata dan dapat dilihat Pada Tabel 2.

Tabel 2 Hasil Uji Beda Rata-Rata Gum Arab Terhadap Kadar Protein

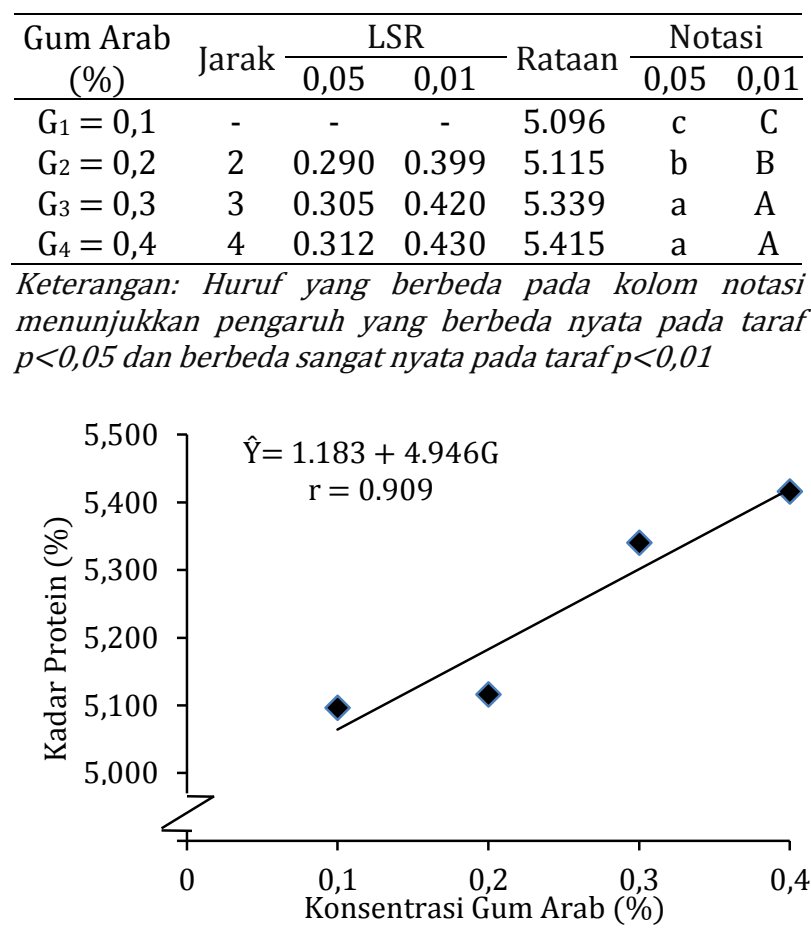

Gambar 2 Pengaruh Gum Arab terhadap Kadar Protein

Pada Gambar 2 dapat dilihat bahwa semakin tinggi konsentrasi gum arab maka kadar protein akan semakin meningkat. Hal ini disebabkan karena gum arab mengandung glikoprotein (Stephen, 1995). Semakin tinggi konsentrasi gum arab yang ditambahkan maka glikoprotein pada susu kedelai akan semakin tinggi sehingga protein meningkat. Glikoprotein penyusun gum arab tersebut. Memberikan kontribusi pada kenaikan kadar protein susu kedelai (Sutardi et al, 2010). 


\section{Antioksidan (\%)}

\section{Pengaruh Penambahan Ekstrak Kulit Buah Naga}

Penambahan ekstrak kulit buah naga memberikan pengaruh yang berbeda sangat nyata( $p<0,01)$ terhadap antioksidan. Tingkat perbedaan tersebut telah di uji dengan uji beda rata-rata dan dapat dilihat pada Tabel 3.

Tabel 3 Hasil Uji Beda Rata-Rata Penambahan Ekstrak Kulit Buah Naga Terhadap Antioksidan

\begin{tabular}{|c|c|c|c|c|c|c|}
\hline \multirow{2}{*}{$\begin{array}{c}\text { Penambahan } \\
\text { Ekstrak Kulit } \\
\text { Buah Naga (\%) }\end{array}$} & \multirow[b]{2}{*}{ Jarak } & \multicolumn{2}{|c|}{ LSR } & \multicolumn{3}{|c|}{ Notasi } \\
\hline & & 0,05 & 0,01 & Rataan & 0,05 & 0,01 \\
\hline $\mathrm{D}_{1}=20 \%$ & - & - & - & 45.133 & $d$ & $\mathrm{D}$ \\
\hline $\mathrm{D}_{2}=40 \%$ & 2 & 0.047 & 0.064 & 51.646 & c & $\mathrm{C}$ \\
\hline $\mathrm{D}_{3}=60 \%$ & 3 & 0.049 & 0.067 & 57.405 & $\mathrm{~b}$ & B \\
\hline $\mathrm{D}_{4}=80 \%$ & 4 & 0.050 & 0.069 & 64.737 & $\mathrm{a}$ & A \\
\hline
\end{tabular}

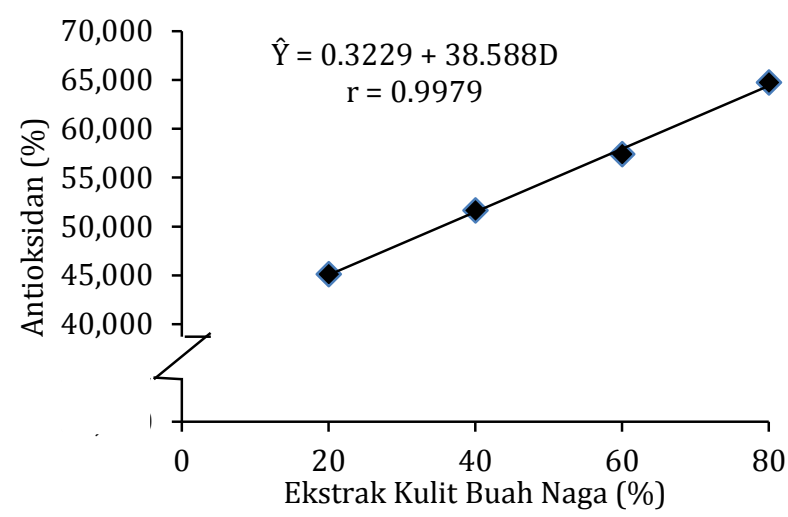

Gambar 3 Pengaruh Penambahan Ekstrak Kulit Buah Naga Terhadap Antioksidan

Pada Gambar 3 dapat dilihat bahwa semakin tinggi penambahan ekstrak kulit buah naga maka antioksidan akan semakin meningkat. Hal ini dikarenakan ekstrak kulit buah naga merah mengandung betasianin dan antosianin dan memiliki aktivitas penghambahan terhadap radikal yang cukup tinggi.Antosianin dan betasianin dalam ekstrak kulit buah naga merah memiliki kemampuan dalam menangkal radikal bebas DPPH dengan cukup baik sehingga sangat potensial untuk dijadikan sebagai suplemen antioksidan. Oleh karena itu, ketika dalam formulasi pembuatan susu kedelai dilakukan pencampuran antara ekstrak kulit buah naga merah dan sari susu kedelai maka dapat menghasilkan susu kedelai dengan nilai aktivitas antioksidan yang tinggi seiring dengan bertambahnya jumlah konsentrasi ekstrak kulit buah naga (Pribadi et al, 2014).

\section{Pengaruh Gum Arab}

Dari daftar sidik ragam dapat dilihat bahwa gum arab memberikan pengaruh yang berbeda sangat nyata $(\mathrm{p}<0,01)$ terhadap antioksidan. Tingkat perbedaan tersebut telah di uji dengan uji beda rata-rata dan dapat dilihat Pada Tabel 4.

Tabel 4 Hasil Uji Beda Rata-Rata Gum Arab Terhadap Antioksidan

\begin{tabular}{ccccccc}
\hline Gum Arab & \multirow{2}{*}{ Jarak } & \multicolumn{2}{c}{ LSR } & \multirow{2}{*}{ Rataan } & \multicolumn{2}{c}{ Notasi } \\
\cline { 3 - 7 } & 0,05 & 0,01 & & 0,05 & 0,01 \\
\hline $\mathrm{G}_{1}=0,1$ & - & - & - & 51.718 & $\mathrm{D}$ & $\mathrm{D}$ \\
$\mathrm{G}_{2}=0,2$ & 2 & 0.047 & 0.064 & 54.148 & $\mathrm{C}$ & $\mathrm{C}$ \\
$\mathrm{G}_{3}=0,3$ & 3 & 0.049 & 0.067 & 55.887 & $\mathrm{~B}$ & $\mathrm{~B}$ \\
$\mathrm{G}_{4}=0,4$ & 4 & 0.050 & 0.069 & 57.167 & $\mathrm{~A}$ & $\mathrm{~A}$ \\
\hline
\end{tabular}

Keterangan: Huruf yang berbeda pada kolom notasi menunjukkan pengaruh yang berbeda nyata pada taraf $p<0,05$ dan berbeda sangat nyata pada taraf $p<0,01$

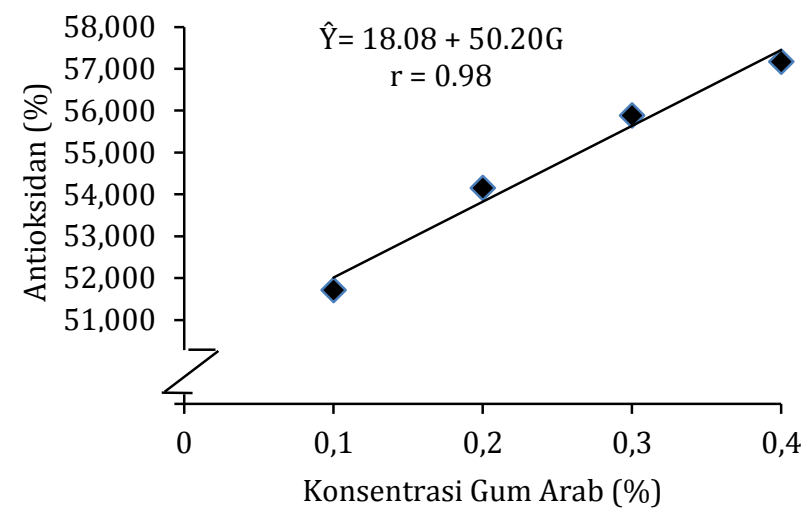

Gambar 4 Pengaruh Gum Arab terhadap Antioksidan

Pada gambar 4 dapat dilihat bahwa semakin tinggi penambahan konsentrasi gum arab maka antioksidan akan semakin tinggi. Hal ini disebabkan Gum arab dapat meningkatkan stabilitas dengan peningkatan viskositas dan juga tahan pada proses pengolahan menggunakan panas sehingga daya untuk mengikat kandungan dalam bahan akan semakin tinggi seiring bertambah nya jumlah konsentrasi gum arab. Menurut Alikonis (1979), gum arab dapat digunakan untuk pengikatan flavor, bahan pengental, pembentuk lapisan tipis dan pemantap emulsi. Persen aktivitas antioksidan dipengaruhi oleh sifat bahan pengikat gum arab yang dapat membentuk tekstur, membentuk film, mengikat dan mengemulsi yang baik sehingga gum arab dapat 
mempertahankan material inti yaitu antioksidan dalam susu kedelai karena bahan pengikat gum arab dapat membentuk lapisan yang dapat melindungi material inti antioksidan dari proses perubahan dekstruktif yang melibatkan pemanasan (Thevenet, 1998 dalam Desmawarni, 2007). Didukung oleh Anam et al (2013), proses pengolahan bahan pangan yang mengandung antioksidan yang melibatkan pemanasan dengan suhu yang tinggi dapat diminimalisir kerusakannya dengan menggunakan bahan pengikat gum arab.

\section{pH}

\section{Pengaruh Penambahan Ekstrak Kulit Buah Naga}

Dari daftar sidik ragam dapat dilihat bahwa penambahan ekstrak kulit buah naga memberikan pengaruh yang berbeda sangat nyata $(\mathrm{p}<0,01)$ terhadap $\mathrm{pH}$. Tingkat perbedaan tersebut telah di uji dengan uji beda rata-rata dan dapat dilihat pada Tabel 5 .

Tabel 5 Hasil Uji Beda Rata-Rata Penambahan Ekstrak Kulit Buah Naga Terhadap pH

\begin{tabular}{|c|c|c|c|c|c|c|}
\hline \multirow{2}{*}{$\begin{array}{c}\text { Penambahan } \\
\text { Ekstrak Kulit } \\
\text { Buah Naga (\%) }\end{array}$} & \multirow[b]{2}{*}{ Jarak } & \multicolumn{2}{|c|}{ LSR } & \multirow[b]{2}{*}{ Rataan } & \multicolumn{2}{|c|}{ Notasi } \\
\hline & & 0,05 & 0,01 & & $\overline{0,05}$ & $\overline{0,01}$ \\
\hline $\mathrm{D}_{1}=20 \%$ & - & - & - & 4.256 & $\mathrm{a}$ & A \\
\hline $\mathrm{D}_{2}=40 \%$ & 2 & 0.019 & 0.027 & 4.222 & $\mathrm{~b}$ & B \\
\hline $\mathrm{D}_{3}=60 \%$ & 3 & 0.020 & 0.028 & 4.168 & C & $\mathrm{C}$ \\
\hline $\mathrm{D}_{4}=80 \%$ & 4 & 0.021 & 0.029 & 4.151 & C & $\mathrm{C}$ \\
\hline
\end{tabular}

Keterangan: Huruf yang berbeda pada kolom notasi menunjukkan pengaruh yang berbeda nyata pada taraf $p<0,05$ dan berbeda sangat nyata pada taraf $p<0,01$

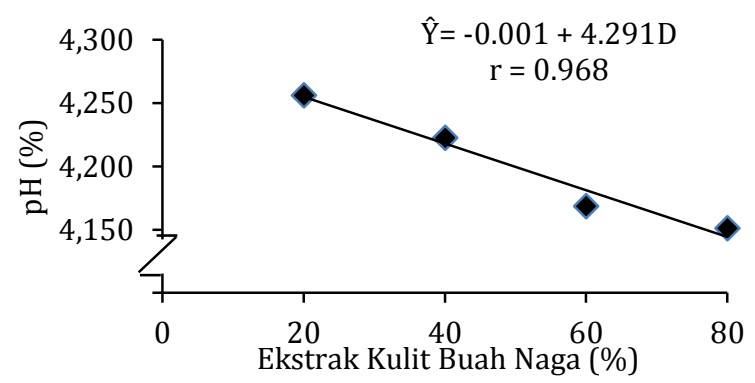

Gambar 5 Pengaruh Penambahan Ekstrak Kulit Buah Naga terhadap $\mathrm{pH}$

Pada Gambar 5 dapat dilihat bahwa semakin tinggi penambahan ekstrak kulit buah naga maka $\mathrm{pH}$ akan semakin menurun. Hal ini disebabkan semakin tinggi jumlah penambahan ekstrak kulit buah naga.Penurunan nilai $\mathrm{pH}$ terjadi akibat bertambahnya kandungan antosianin dan betasianin yang terdegradasi yang menyebabkan nilai $\mathrm{pH}$ menurun. Simanjuntak et al (2014). Keadaan yang asam akan menyebabkan banyaknya pigmen antosianin berada dalam bentuk kation flavilium atau oksonium yang berwarna dan pengukuran absorbansi akan menunjukkan jumlah betasianin dan antosianin yang semakin besar. Disamping itu keadaan yang semakin asam menyebabkan semakin banyak dinding sel vakuola yang pecah sehingga pigmen betasianin dan antosianin semakin banyak yang terekstrak (Moulana et al, 2012).

\section{Pengaruh Gum Arab}

Dari daftar sidik ragam dapat dilihat bahwa gum arab memberikan pengaruh yang berbeda sangat nyata $(\mathrm{p}<0,01)$ terhadap $\mathrm{pH}$. Tingkat perbedaan tersebut telah di uji dengan uji beda rata-rata dan dapat dilihat Pada Tabel 6

Tabel 6 Hasil Uji Beda Rata-Rata Gum Arab Terhadap $\mathrm{pH}$

\begin{tabular}{ccccccc}
\hline Gum Arab & \multirow{2}{*}{$\begin{array}{c}\text { LSR } \\
(\%)\end{array}$} & Jarak & \multicolumn{2}{c}{ Rataan } & \multicolumn{2}{c}{ Notasi } \\
\cline { 3 - 7 } & & 0,05 & 0,01 & & 0,05 & 0,01 \\
\hline $\mathrm{G}_{1}=0,1$ & - & - & - & 4.216 & $\mathrm{~A}$ & $\mathrm{~A}$ \\
$\mathrm{G}_{2}=0,2$ & 2 & 0.019 & 0.027 & 4.206 & $\mathrm{~A}$ & $\mathrm{~A}$ \\
$\mathrm{G}_{3}=0,3$ & 3 & 0.020 & 0.028 & 4.192 & $\mathrm{~B}$ & $\mathrm{~A}$ \\
$\mathrm{G}_{4}=0,4$ & 4 & 0.021 & 0.029 & 4.183 & $\mathrm{Bc}$ & $\mathrm{B}$ \\
\hline
\end{tabular}

Keterangan: Huruf yang berbeda pada kolom notasi menunjukkan pengaruh yang berbeda nyata pada taraf $p<0,05$ dan berbeda sangat nyata pada taraf $p<0,01$

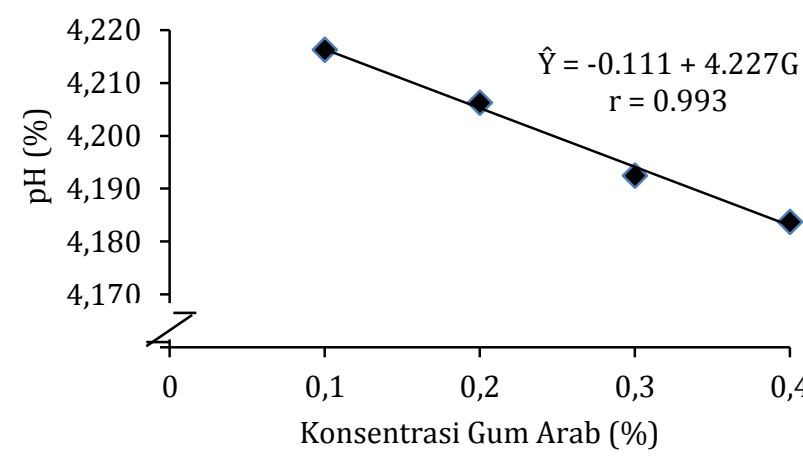

Gambar 6 Pengaruh Gum Arab terhadap pH

Pada Gambar 6 dapat dilihat bahwa semakin tinggi konsentrasi gum arab maka nilai pH semakin menurun. Hal ini disebabkan pemberian konsentrasi gum arab yang berbeda, maka semakin bertambah konsentrasi gum arab sebagai bahan penstabil akan menyebabkan larutan dalam minuman menjadi asam. Hal ini sependapat dengan Sutardi et al (2010), yang menyatakan gum arab memiliki berat molekul tinggi, struktur 
molekulnya kompleks, dan terdapat sejumlah besar pati di dalamnya, sehingga sifatnya lebih higroskopis dan komplek, maka akibatnya air pada bahan lebih banyak tertahan dan sulit diuapkan. Perubahan $\mathrm{pH}$ yang cenderung menurun seiring dengan meningkatnya perlakuan disebabkan gum arab memiliki $\mathrm{pH}$ alami sekitar 3,9 - 4,9 sehingga $\mathrm{pH}$ minuman produk yang ditambahkan bahan penstabil gum arab semakin stabil sesuai dengan $\mathrm{pH}$ gum arab (Febryanto, 2008). Apabila bahan dilarutkan dalam air, maka perbandingan ion hidrogen terhadap ion hidroksil akan berubah. Jika jumlah ion hidrogen lebih besar daripada jumlah ion hidroksil, larutannya bersifat asam sehingga $\mathrm{pH}$ menjadi turun, begitu pula sebaliknya (Prabandari, 2011).

\section{Organoleptik Rasa}

\section{Pengaruh Penambahan Ekstrak Kulit Buah Naga}

Dari daftar sidik ragam dapat dilihat bahwa penambahan ekstrak kulit buah naga memberikan pengaruh yang berbeda sangat nyata $(\mathrm{p}<0,01)$ terhadap organoleptik rasa. Tingkat perbedaan tersebut telah di uji dengan uji beda rata-rata dan dapat dilihat pada Tabel 7.

Tabel 7 Hasil Uji Beda Rata-Rata Penambahan Ekstrak Kulit Buah Naga Terhadap Organoleptik Rasa

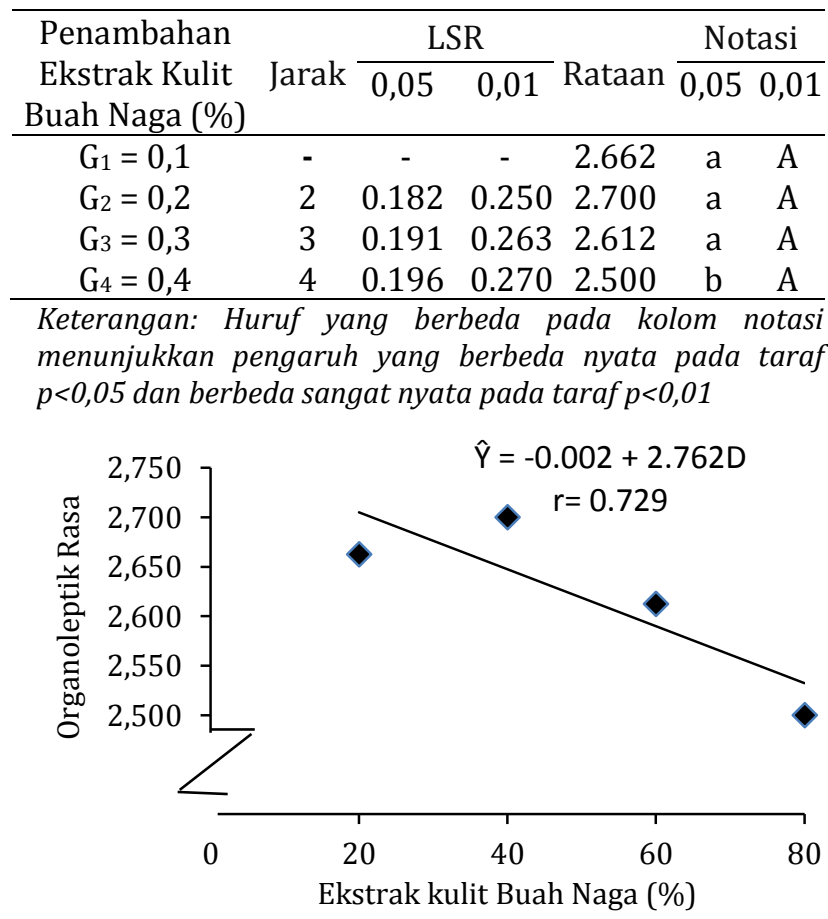

Gambar 7 Pengaruh Penasmbahan Ekstrak Kulit Buah Naga terhadap Rasa
Pada Gambar 7 dapat dilihat bahwa semakin tinggi penambahan ekstrak kulit buah naga maka grafik rasa akan semakin menurun. Hal ini disebabkan karena semakin besar konsentrasi ekstrak kulit buah naga yang ditambahkan maka tingkat kesukaan panelis terhadap parameter rasa semakin menurun. Hal ini disebabkan karena adanya rasa langu dalam ekstrak kulit buah naga yang sebanding dengan besarnya penambahan konsentrasi ekstrak kulit buah naga sehingga menurunkan kesukaan penelis terhadap parameter rasa.Menurut Winarno (1997), Rasa merupakan respon lidah terhadap rangsangan yang diberikan oleh suatu makanan. Penerimaan panelis terhadap rasa dipengaruhi oleh beberapa faktor antara lain kandungan senyawa kimia, suhu, konsentrasi bahan dan interaksi komponen lain.

\section{Pengaruh Gum Arab}

Dari daftar sidik ragam dapat dilihat bahwa gum arab memberikan pengaruh yang berbeda sangat nyata $(\mathrm{p}<0,01)$ terhadap organoleptik rasa. Tingkat perbedaan tersebut telah di uji dengan uji beda rata-rata dan dapat dilihat Pada Tabel 8.

Tabel 8 Hasil Uji Beda Rata-Rata Gum Arab Terhadap Organoleptik Rasa

\begin{tabular}{ccccccc}
\hline \multirow{2}{*}{$\begin{array}{c}\text { Gum Arab } \\
(\%)\end{array}$} & \multirow{2}{*}{ Jarak } & \multicolumn{2}{c}{ LSR } & \multirow{2}{*}{ Rataan } & \multicolumn{2}{c}{ Notasi } \\
\cline { 3 - 7 } & & 0,05 & 0,01 & & 0,05 & 0,01 \\
\hline $\mathrm{G}_{1}=0,1$ & - & - & - & 2.462 & $\mathrm{~b}$ & $\mathrm{~B}$ \\
$\mathrm{G}_{2}=0,2$ & 2 & 0.182 & 0.250 & 2.562 & $\mathrm{a}$ & $\mathrm{A}$ \\
$\mathrm{G}_{3}=0,3$ & 3 & 0.191 & 0.263 & 2.700 & $\mathrm{a}$ & $\mathrm{A}$ \\
$\mathrm{G}_{4}=0,4$ & 4 & 0.196 & 0.270 & 2.750 & $\mathrm{a}$ & $\mathrm{A}$ \\
\hline
\end{tabular}

Keterangan: Huruf yang berbeda pada kolom notasi menunjukkan pengaruh yang berbeda nyata pada taraf $p<0,05$ dan berbeda sangat nyata pada taraf $p<0,01$

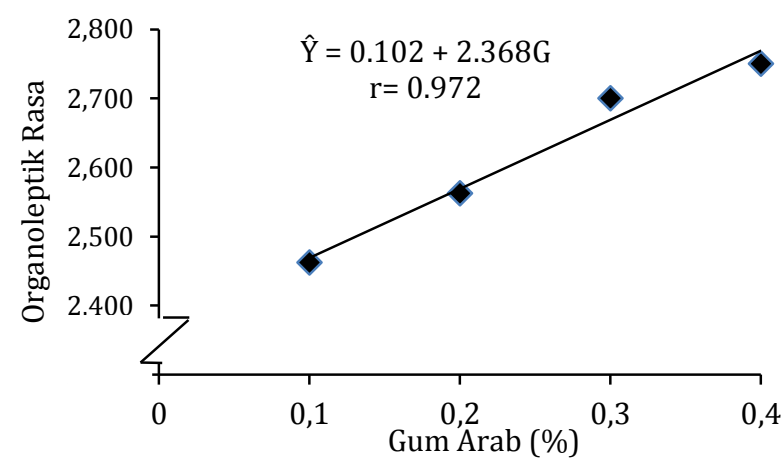

Gambar 8 Pengaruh Gum Arab terhadap Rasa

Pada Gambar 8 dapat dilihat bahwa semakin tinggi konsentrasi gum arab maka rasa akan semakin meningkat. Hal ini disebabkan karena 
Gum arab yang diberikan akan membentuk larutan yang tidak begitu kental dan tidak membentuk gel pada kepekatan yang biasa digunakan, maka semakin banyak pemberian gum arab, maka semakin tinggi kepekatan dan kekentalan pada minuman. Didukung oleh Alikonis (1979), gum arab dapat digunakan untuk meningkatkan rasa dan aroma, bahan pengental, pembentuk lapisan tipis dan pemantap emulsi.

\section{Organoleptik Warna \\ Pengaruh Penambahan Ekstrak Kulit Buah Naga}

Dari daftar sidik ragam dapat dilihat bahwa penambahan ekstrak kulit buah naga memberikan pengaruh yang berbeda sangat nyata $(p<0,01)$ terhadap organoleptik warna. Tingkat perbedaan tersebut telah di uji dengan uji beda rata-rata dan dapat dilihat pada Tabel 9.

Tabel 9 Hasil Uji Beda Rata-Rata Penambahan Ekstrak Kulit Buah Naga Terhadap Organoleptik Warna

\begin{tabular}{cccccccc}
\hline Penambahan & & \multicolumn{2}{c}{ LSR } & & \multicolumn{2}{c}{ Notasi } \\
\cline { 3 - 5 } $\begin{array}{c}\text { Ekstrak Kulit } \\
\text { Buah Naga (\%) }\end{array}$ & & 0,05 & 0,01 & & & 0,05 & 0,01 \\
\hline $\mathrm{D}_{1}=20 \%$ & - & - & - & 2.712 & $\mathrm{c}$ & $\mathrm{C}$ \\
$\mathrm{D}_{2}=40 \%$ & 2 & 0.088 & 0.121 & 2.787 & $\mathrm{c}$ & $\mathrm{B}$ \\
$\mathrm{D}_{3}=60 \%$ & 3 & 0.092 & 0.127 & 2.837 & $\mathrm{~b}$ & $\mathrm{~A}$ \\
$\mathrm{D}_{4}=80 \%$ & 4 & 0.095 & 0.130 & 2.862 & $\mathrm{a}$ & $\mathrm{A}$ \\
\hline
\end{tabular}

Keterangan: Huruf yang berbeda pada kolom notasi menunjukkan pengaruh yang berbeda nyata pada taraf $p<0,05$ dan berbeda sangat nyata pada taraf $p<0,01$

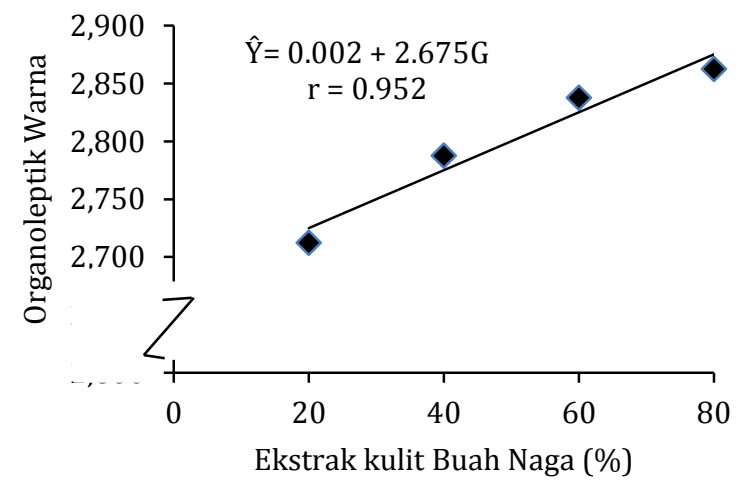

Gambar 9 Pengaruh Penambahan Ekstrak Kulit Buah Naga terhadap Warna

Pada Gambar 9 dapat dilihat bahwa semakin tinggi penambahan Ekstrak Kulit Buah Naga maka grafik warna akan semakin meningkat. Hal ini disebabkan Semakin tinggi konsentrasi ekstrak yang ditambahkan maka warna yang dihasikan produk menjadi lebih pekat atau kuat, karena dalam kulit buah naga mengandung pigmen antosianin yang menyebabkan berwarna ungu, ketika jumlah konsentrasi ekstrak kulit buah naga yang digunakan semakin tinggi maka presentase antosianin juga semakin tinggi sehingga warna ungu akan semakin kuat atau pekat. Didukung oleh pernyataan Hidayah (2013), kulit buah naga dapat menghasilkan warna ungu yang dihasikan oleh pigmen antosianin.

\section{Pengaruh Gum Arab}

Dari daftar sidik ragam dapat dilihat bahwa gum arab memberikan pengaruh yang berbeda sangat nyata $(\mathrm{p}<0,01)$ terhadap organoleptik warna. Tingkat perbedaan tersebut telah di uji dengan uji beda rata-rata dan dapat dilihat Pada Tabel 10 .

Tabel 10 Hasil Uji Beda Rata-Rata Gum Arab Terhadap Organoleptik Warna

\begin{tabular}{ccccccc}
\hline Gum Arab & \multirow{2}{*}{ Jarak } & \multicolumn{2}{c}{ LSR } & \multirow{2}{*}{ Rataan } & \multicolumn{2}{c}{ Notasi } \\
\cline { 3 - 7 }$(\%)$ & & 0,05 & 0,01 & & 0,05 & 0,01 \\
\hline $\mathrm{G}_{1}=0,1$ & - & - & - & 2.650 & $\mathrm{D}$ & $\mathrm{D}$ \\
$\mathrm{G}_{2}=0,2$ & 2 & 0.088 & 0.121 & 2.725 & $\mathrm{C}$ & $\mathrm{C}$ \\
$\mathrm{G}_{3}=0,3$ & 3 & 0.092 & 0.127 & 2.862 & $\mathrm{~B}$ & $\mathrm{~B}$ \\
$\mathrm{G}_{4}=0,4$ & 4 & 0.095 & 0.130 & 2.962 & $\mathrm{~A}$ & $\mathrm{~A}$ \\
\hline
\end{tabular}

Keterangan: Huruf yang berbeda pada kolom notasi menunjukkan pengaruh yang berbeda nyata pada taraf $p<0,05$ dan berbeda sangat nyata pada taraf $p<0,01$

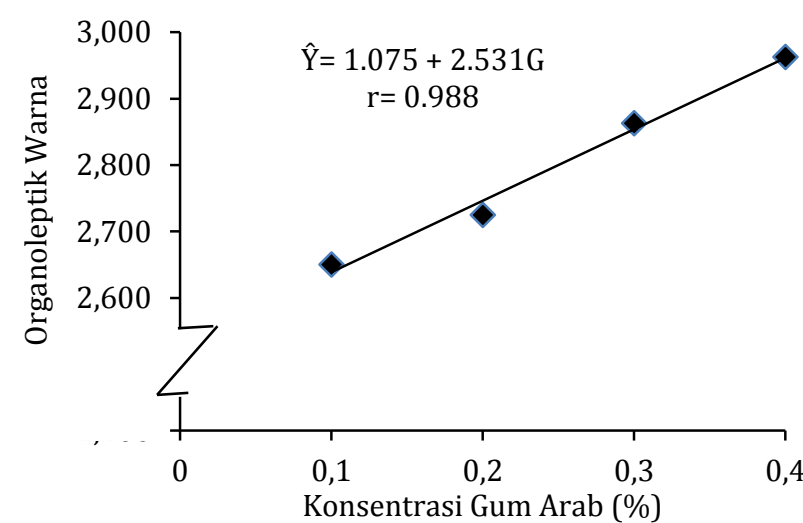

Gambar 10 Pengaruh Penambahan gum arab terhadap Warna

Pada Gambar 10 dapat dilihat bahwa semakin tinggi konsentrasi gum arab maka warna akan semakin meningkat. Hal ini disebabkan oleh kekentalan produk yang semakin meningkat dengan penambahan konsentrasi gum arab, sehingga warna susu menjadi lebih stabil. Sesuai dengan pernyataan Estiasih dan Ahmadi (2009) yang menyatakan 
bahwa zat penstabil mempunyai sifat sebagai pengental. Hal tersebut mempengaruhi kesukaan panelis terhadap warna produk yang dihasilkan karena warna mempengaruhi penilaian panelis. Warna susu tidak terlalu signifikan mencolok berbeda, karena penerimaan warna suatu bahan berbeda-beda.

\section{KESIMPULAN}

Dari hasil penelitian dan pembahasan mengenai aplikasi ekstrak kulit buah naga merah (hylocereus polyrhizus) pada pembuatan susu kedelai dapat disimpulkan sebagai berikut:

1. Penambahan ekstrak kulit buah naga memberikan pengaruh yang berbeda sangat nyata pada taraf $\mathrm{p}<0,01$ terhadap kadar protein, antioksidan, $\mathrm{pH}$, organoleptik rasa dan warna.

2. Kosentrasi gum arab memberikan pengaruh berbeda sangat nyata pada taraf $\mathrm{p}<0,01$ terhadap kadar protein, antioksidan, $\mathrm{pH}$, organoleptik rasa dan warna.

3. Perlakuan terbaik pada penelitian ini adalah pada perlakuan $\mathrm{D}_{4} \mathrm{G}_{4}$ yaitu dengan nilai rataan antioksidan 68.745 .

\section{DAFTAR PUSTAKA}

Alikonis, J. J. 1979. Candy Technology. The AVI Publishing Co.Westport Connecticut.

Anam, C., Andriani, M.A.M., Alvin, A. 2013. Pengaruh Jenis Dan Konsenstrasi Bahan Pengikat Terhadap Karakteristik Fisik Serta Analisa Aktivitas Antioksidan Tablet Effervescent Dari Ekstrak Buah Beet (Beta vulgaris). Jurnal Teknosains Pangan. 2(2): 39-44

Desmawarni.2007. Pengaruh Komposisi Bahan Penyalut dan Kondisi Spray Drying Terhadap Karakteristik Mikroenkapsulasi Oleoresinjahe. [Skripsi]. Fakultas Teknologi Pertanian. Institut Pertanian Bogor. Bogor

Estiasih, T. dan Ahmadi K. 2009. Teknologi Pengolahan Pangan. Jakarta: PT. Bumi Aksara.

Febryanto, E. O. 2008. Colloides Naturels International Memperkenalkan Keunggulan dan Nilai lebih Gum acacia. Jakarta: PT Indesso Niagatama.
Hidayah, Tri. 2013. Uji Stabilitas Pigmen dan Antioksidan Hasil Ekstraksi Zat Warna Alami dari Kulit Buah Naga (Hylocereus undatus). [Skripsi]. Universitas Negeri Semarang

Li Chen Wu, Hsiu-Wen Hsu, Yun- Chen Chen, Chih-Chung Chiu, Yu-In Lin and Annie Ho . 2005. Antioxidant And Anti proliferative Activities Of Red. London: Cambridge University Press. hal 54-66

Marhazlina, M. 2008. Departement of Nutrition and Dietetic Faculty of Medicineand ealth Sciences. University Putra, Malaysia

Mitasari, A. 2012. Uji Aktivitas Ekstrak Kloroform Kulit buah Naga Merah (Hylocereus polyrhizus Britton \& Rose) Menggunakan Metode DPPH (1,1-Defenil2-PikrilHidrazil). [Skripsi]. Universitas Tanjungpura.

Moulana, R., Juanda., Rohaya, S., Rosika, R. 2012. Efektivitas Penggunaan Jenis Pelarut dan Asam dalam Proses Ekstraksi Pigmen Antosianin Kelopak Bunga Rosella (Hibiscus sabdariffa L). JTIP. 4(3): 20-25

Pribadi YS, Sukatiningsih, P Sari. 2014. Formulasi Tablet Effervescent Berbahan Baku Kulit Buah Naga Merah (Hylocereus polyrhizus) Dan Buah Salam (Syzygium polyanthum [Wight.] Walp). Berkala Ilmiah Pertanian. 1(4): 86-89

Prabandari, W. 2011. Pengaruh Berbagai Jenis Bahan Penstabil Terhadap Karakteristik Fisikokimia Dan Organoleptik Yoghurt Jagung. [Skripsi]. Universitas Sebelas Maret. Surakarta

Simanjuntak, L., Sinaga, C., Fatimah. 2014. Ekstraksi Pigmen Antosianin dari Kulit Buah Naga Merah (Hylocereus polyrhizus). Jurnal Teknik Kimia USU. 3(2): 25-29.

Sulistyowati, R. 2014. Uji Kadar Protein Dan Organoleptik Yoghurt Susu Kedelai (Glycine Max) Dengan Penambahan Ekstra Buah Nangka (Artocarpus Heterophyllus) Dan Ekstra Kulit Buah Naga (Hylocereus Polyrhizuz). [Skripsi]. Universitas Muhammadiyah Surakarta

Sutardi, S., Hadiwiyoto dan C.R.N. Murti. 2010. Pengaruh Dekstrin dan Gum Arab Terhadap Sifat kimia dan Fisik Bubuk Sari Jagung Manis. Jurnal Teknologi dan industri Pangan. 21(2): 102-107.

Wahyuni, R., dan Nugroho, M. 2014. Pengaruh Penambahan Ekstrak Kulit Buah Naga Super Merah Terhadap Produk Mie 
Kering. Jurnal Teknologi Pertanian. 15(2):

93-102.

Winarsih, S., 2007. Mengenal dan

Membudidayakan Buah Naga. Semarang:

CV Aneka Ilmu

Winarno, F.G. 1997. Kimia Pangan dan Gizi.

Jakarta: Gramedia Pustaka Utama. 